\title{
The addition of fluted pumpkin (Telfairia occidentalis) leaf powder improves the techno-functional properties of cassava pasta
}

\author{
Oluranti M. Lawal ${ }^{\mathrm{a}, \mathrm{b}}$, Oluwatofunmi Sanni ${ }^{\mathrm{a}}$, Matthew Oluwamukomi ${ }^{\mathrm{b}}$, Vincenzo Fogliano ${ }^{\mathrm{a}}$, \\ Anita R. Linnemann ${ }^{\text {a, }}$, \\ ${ }^{a}$ Food Quality and Design, Wageningen University and Research, P.O. Box 17, 6700 AA Wageningen, The Netherlands \\ ${ }^{\mathrm{b}}$ Food Science and Technology Department, Federal University of Technology, Akure Nigeria
}

\section{A R T I C L E I N F O}

\section{Keywords:}

Cassava

Fluted pumpkin

Pasta

Pasting

Functional

\begin{abstract}
A B S T R A C T
In this study, techno-functional and sensorial properties of cassava pasta, as influenced by incorporating fluted pumpkin leaf ("ugwu") powder and the cultivar variation effect were evaluated. Fortification of cassava pasta with the leaf powder at incorporation levels of 5\% and $10 \%$ decreased the particle sizes of the products while yellow cassava flour showed larger particle size distribution than the white cultivar. Pasta colour was significantly impacted, as lightness values reduced with an increase in leaf powder. Fluted pumpkin inclusion decreased the gelation capacity of the flour blends but enhanced the water solubility, swelling power and oil absorption capacities of the products. Interestingly, the cooking time and gruel solid loss were reduced while the weight gain increased in the formulated pasta improved with the addition of fluted pumpkin leaf powder. The textural properties of the cassava pasta were enhanced as the hardness and pasting viscosities of the gel and pasta decreased by $12 \%$ with leaf powder inclusion. Pasting temperatures were also lower in the fluted pumpkinfortified pasta than the gluten-laden wheat pasta. Furthermore, the yellow cassava products had significantly higher pasting viscosities than the white cassava products and cultivar variation had significant effects on the thermal properties of the food products. Overall acceptability and likelihood of purchase of the novel pasta were modest among the consumers. Our results showed that incorporating fluted pumpkin leaf powder in cassava pasta led to some improvements in the techno-functional and altered sensorial attributes.
\end{abstract}

\section{Introduction}

Micronutrient deficiencies, also known as hidden hunger, are public health issues affecting resource-poor populations in sub-Saharan Africa. The low-income earners are mostly affected because of the high dependence on starchy crops and a poor-quality diet low in sources of other food components such as vitamins and minerals (Bouis \& Saltzman, 2017). In Nigeria, for example, average cassava consumption is up to $940 \mathrm{~g} /$ adult/day fresh weight (De Moura et al., 2015). The conventional white cassava is low in micronutrients; hence, its frequent consumption contributes to hidden hunger (Odoemelam et al., 2020). Recent plant breeding research aiming at alleviating hidden hunger in developing countries provided the provitamin A carotenoid biofortified cassava varieties, otherwise known as yellow cassava. With vitamin A, iron and zinc contents of up to 15,4 and $3 \mu \mathrm{g} / \mathrm{g}$ respectively, yellow cassava can contribute about $40 \%, 30 \%$ and $40 \%$ of the estimated average requirement (EAR) for vitamin A, iron and zinc (Eyinla et al.,
2019; Gegios et al., 2010). It has thus become a veritable game-changer in the quest for nutritious alternatives to the more expensive imported wheat flour to produce staples, snacks and convenient food products such as pasta (Ilona, Bouis, Palenberg, Moursi, \& Oparinde, 2017).

An increase in the consumption frequency of pasta products in subSaharan countries has been observed within the last decade (International Pasta Organization, 2020). Pasta products, valued for their convenience, affordability, and long shelf life, are progressively being fortified with vegetable powders to improve their nutritional profile (Simonato et al., 2020; Mercier, Moresoli, Mondor, Villeneuve, \& Marcos, 2016). The high volume of pasta consumption enhances its suitability as a bioactive substance carrier (Michalak Majewska et al., 2020). The food industry recently introduced newer functional pasta products enriched with nutrients and bioactive compounds such as pseudo-cereals, legume flours and vegetable or fruits powders (Gao, Janes, Chaiya, Brennan, Brennan, \& Prinyawiwatkul, 2018), but none has been made with yellow cassava. Thus, in the sub-Saharan Africa

\footnotetext{
* Corresponding author.

E-mail addresses: mukomi2003@yahoo.com (M. Oluwamukomi), vincenzo.fogliano@wur.nl (V. Fogliano), anita.linnemann@wur.nl (A.R. Linnemann).
} 
region, the available, affordable, and nutrient-dense materials can be explored to provide a nutritionally superior pasta product that improves consumers' vitamin A, iron, and zinc status.

Fluted pumpkin (Telfairia occidentalis), known as "ugwu" in Nigeria, is the most preferred, widely cultivated leafy vegetable in Nigeria (Lawal, Talsma, Bakker, Fogliano, \& Linnemann, 2021). The leaves are good sources of vitamins (Vit. A $6120 \mathrm{IU}$ ), minerals (iron $3.6 \mathrm{mg} / 100 \mathrm{~g}$, iron $4.2 \mathrm{mg} / 100 \mathrm{~g}$ ) and proteins (22-39 g/100 g DW), while the seeds are rich in oil and protein (Aworh, 2015; Omimakinde, Oguntimehin, Omimakinde, \& Olaniran, 2018). Including a leafy vegetable such as fluted pumpkin in yellow cassava pasta can improve the pasta's nutritional composition and alter pasta quality attributes such as texture, colour and functional properties (Oliviero \& Fogliano, 2016; Michalak-Majewska, Teterycz, Muszyński, Radzki, \& Sykut-Domańska, 2020).

Previous studies have focused on the physico-functional properties of white cassava but reports on the new yellow-fleshed cassava cultivars are still few (Chisenga, Workneh, Bultosa, \& Laing, 2019; De Moura et al., 2015). More precisely, reports on the impact of leaf powder addition on the techno-functional and sensory properties of yellow cassava flour and pasta are not yet available, despite several studies on wheat-based pasta. We hypothesised that leaf addition modifies the structure of the formulated pasta. Thus, this study aimed at evaluating, for the first time, the influence of fluted pumpkin leaf powder addition on the functional, textural, pasting, thermal, cooking and sensory properties of yellow-and white-fleshed cassava flours and pasta. The technological feasibility of leaf fortification on yellow cassava pasta structure was also ascertained. Thus, these outcomes provided knowledge into the possibilities of using yellow cassava flour and its fluted pumpkin-fortified equivalent as a wheat substitute to benefit the health status of its consumers.

\section{Materials and methods}

\subsection{Materials}

Yellow cassava flour was obtained from the International Institute for Tropical Agriculture (IITA), Ibadan, Nigeria, packaged in food-safe polyethylene pouches, shipped on dry ice and stored at $-20{ }^{\circ} \mathrm{C}$ until further analysis. Conventional white cassava flour was purchased from Toko Indrani, Wageningen, Netherlands.

\subsubsection{Preparation of leaf powder}

Fluted pumpkin vegetables were cultivated at the Unifarm of Wageningen University and Research, Netherlands. After harvest, they were freeze-dried, milled into powder with a cryogenic grinder (6875D Freezer/Mill ${ }^{\circledR}$, SPEX SamplePrep, New Jersey, USA) and stored at $20{ }^{\circ} \mathrm{C}$ until further analysis.

\subsubsection{Preparation of pasta}

The sample formulations are shown in Table 1 . The pasta samples

Table 1

Blend formulations of cassava samples.

\begin{tabular}{ll}
\hline Code & Formulation \\
\hline WFU0 & $100 \%$ white cassava flour \\
WFU5 & $95 \%$ white cassava flour $+5 \%$ fluted pumpkin powder \\
WFU10 & $90 \%$ white cassava flour $+10 \%$ fluted pumpkin powder \\
YFU0 & $100 \%$ yellow cassava flour \\
YFU5 & $95 \%$ yellow cassava flour $+5 \%$ fluted pumpkin powder \\
YFU10 & $90 \%$ yellow cassava flour $+10 \%$ fluted pumpkin powder \\
WPU0 & $100 \%$ white cassava flour pasta \\
WPU5 & $95 \%$ white cassava flour $+5 \%$ fluted pumpkin pasta \\
WPU10 & $90 \%$ white cassava flour $+10 \%$ fluted pumpkin pasta \\
YPU0 & $100 \%$ yellow cassava flour pasta \\
YPU5 & $95 \%$ yellow cassava flour $+5 \%$ fluted pumpkin pasta \\
YPU10 & $90 \%$ yellow cassava flour $+10 \%$ fluted pumpkin pasta \\
\hline
\end{tabular}

were produced as described by Sakurai, Rodrigues, Pires, and Silva (2019) with some modifications. The cassava flour samples with $0 \mathrm{~g}, 5 \mathrm{~g}$ into $95 \mathrm{~g}$ and $10 \mathrm{~g}$ into $90 \mathrm{~g}$ of fluted pumpkin leaf powder were weighed and mixed manually to achieve a homogenous mixture. The dry formulation was mixed with boiling water in a ratio of 1:1 to form a dough which was manually kneaded and allowed to rest for $20 \mathrm{~min}$. The dough was fed through a laboratory-scale pasta machine (Pasta machine RVS, Gusta, Zeeland, Netherlands) to produce the desired pasta strands. The pasta strands were dried at $65^{\circ} \mathrm{C}$, packaged with aluminium foil and stored at $-18^{\circ} \mathrm{C}$ until further analyses (Fig. 1).

\subsection{Physical properties determination}

\subsubsection{Particle size distribution}

The particle size distribution of the flour samples was measured by laser scattering technique using a particle size analyser (Mastersizer 3000, Malvern panalytics, UK) following standard operating procedures.

\subsubsection{Colour measurements}

The colour measurements were carried out using a Hunter Lab flex colourimeter (Elscolab, Kruibeke, Belgium). Results were expressed according to the CIE L*a*b* system. The colourimeter was calibrated using standard black and green tiles. Samples were homogenised, placed into the spectrophotometer plastic cuvettes and measured.

\subsection{Determination of functional properties}

\subsubsection{Bulk density and gelation capacity}

Bulk densities of the flour samples were determined according to Ajibola and Olapade (2017), while the least gel concentration (LGC) of the flour samples was determined as described by Chinma et al. (2013).

\subsubsection{Water solubility, swelling power, water holding and oil absorption capacities}

Water solubility and swelling power were determined using a modified version by Chinma et al. (2013) using a shaking water bath (SW23, JULABO, Seelbach, Germany) at 60 and $90{ }^{\circ} \mathrm{C}$ for $30 \mathrm{~min}$. The weight of dry solids was noted to determine water solubility and swelling power. The water holding capacities (WHC) and oil absorption capacities (OAC) were also determined at 60 and $90^{\circ} \mathrm{C}$, as reported by Lu et al. (2020) with slight modification.

\subsubsection{Cooking properties}

The cooking properties of the pasta samples were determined as described by Rathod and Annapure (2017). Five grams ( 5 g) of pasta samples were cooked until the optimal cooking time (OCT), which was noted as when the starchy white core of the pasta disappeared. The cooked pasta samples were rinsed with distilled water $(50 \mathrm{ml})$, drained for $30 \mathrm{~s}$ and weighed to determine the cooking weight gain (WG). The cooking water was collected in an aluminium dish and dried at $110{ }^{\circ} \mathrm{C}$ for $12 \mathrm{~h}$. The residue was weighed, and gruel solid loss (GSL) was reported as a percentage of starting material.

\subsection{Pasting and textural properties}

A Rapid Visco Analyzer (RVA-4, Newport Scientific, Inc., Maryland, USA) was used to determine the pasting properties of the flour and pasta samples were measured in terms of peak viscosity, peak time, pasting temperature, breakdown and setback viscosities and final viscosity as described by Alake et al. (2016). The hardness of the gel formed from the flour samples was investigated according to the method of Baraheng and Karrila (2019) using a texture analyser (TA.XT.plus, Stable Micro Systems, Surrey, UK), while the hardness of gel for pasta samples was as described by Simonato, Trevisan, Tolve, Favati, and Pasini (2019). 


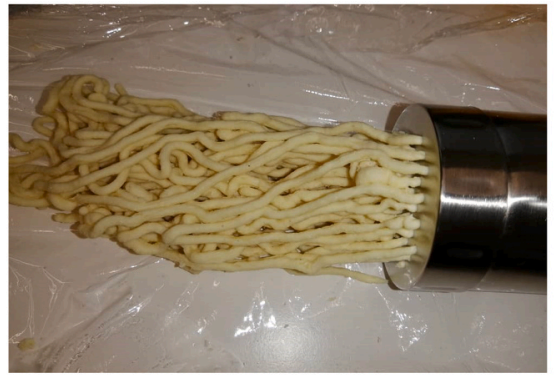

1. Yellow cassava pasta

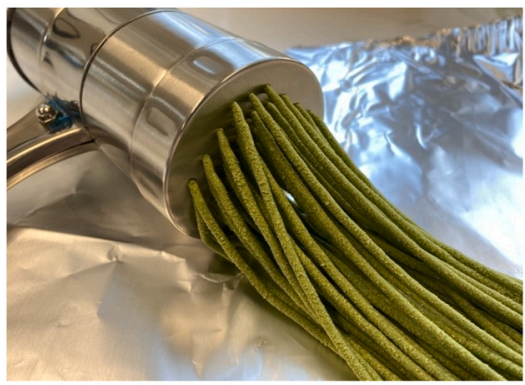

3.Yellow cassava-fluted pumpkin ( $5 \%)$ pasta

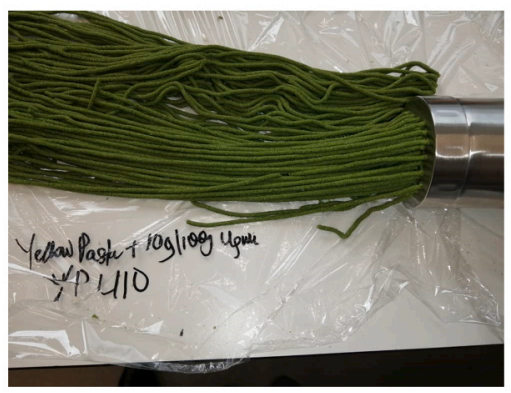

5. Yellow cassava-fluted pumpkin (10\%) pasta

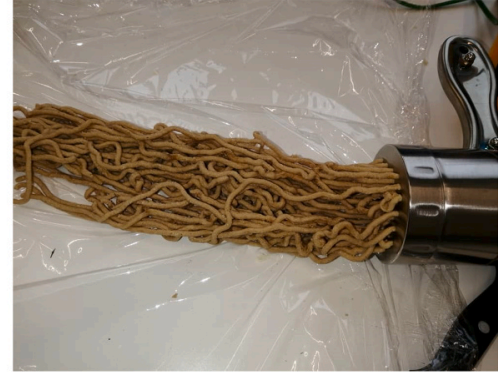

2. White cassava pasta

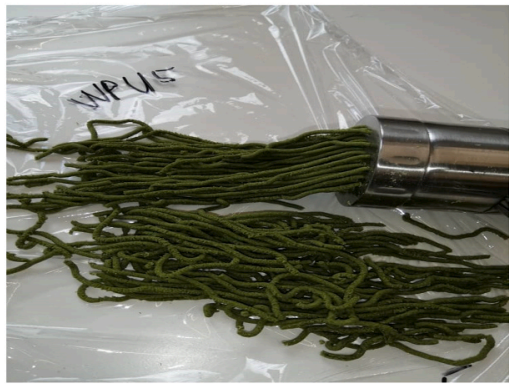

4. White cassava-fluted pumpkin ( $5 \%)$ pasta

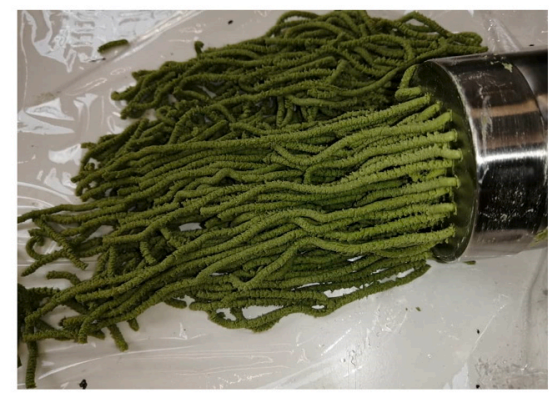

6. White cassava-fluted pumpkin $(10 \%)$ pasta

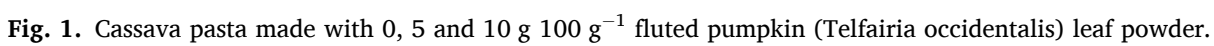

\subsection{Thermal properties}

Thermal properties of the flours and ground pasta samples were investigated with a differential scanning calorimeter (DSC-Q200, TA Instruments, Delaware, USA) as described by Duta et al. (2019). The samples were analysed in the DSC by first equilibrating at $20^{\circ} \mathrm{C}$ for $5 \mathrm{~min}$ and then heated up to $140{ }^{\circ} \mathrm{C}$ at $5{ }^{\circ} \mathrm{C} / \mathrm{min}$.

\subsection{Sensory analysis}

Fifty-four participants (ages 18-27 years, 55\% women, 44\% men) received samples of the fluted pumpkin fortified and commercial cassava pasta in plastic plates $(3 \mathrm{~g})$ at $40{ }^{\circ} \mathrm{C}$ and coded with three-digit random numbers. The participants were recruited through social media and/or personal contact and individuals who habitually eat cassava products were selected. Half of the participants were provided with nutritional information while the other half received none. The samples were evaluated on the overall acceptability, likability and intensity of colour, aroma, appearance, flavour, taste, firmness, stickiness and sliminess and using a 9-point hedonic scale (Michalak-Majewska et al., 2020). The likelihoods of purchase and consumption were also evaluated. The number of participants is adequate for early sensory acceptance evaluations in the development of new products and is commonly used in consumer sensory profiling tests (Costa et al., 2020).

\subsection{Statistical analysis}

All analyses were carried out in triplicate and the results were expressed as mean \pm standard deviation.

The data were subjected to one-way analysis of variance (ANOVA) using the Statistical Package for Social Sciences (IBM SPSS Statistics for Windows, Version 26.0, Armonk, New York, USA). ANOVA and Duncan's multiple range tests were performed at a 95\% confidence interval $(\mathrm{P}<0.05)$ level to determine the significant difference between means.

\section{Results and discussion}

\subsection{Physical properties}

\subsubsection{Particle size distribution (PSD) of flour samples}

The particle size distribution of the investigated flour formulations (Table 2 ) revealed a significant difference $(\mathrm{p}<0.05)$ between the white and yellow cassava flours. The mean volume distribution of the white and yellow cassava flour samples ranged from 135.7 to $149.7 \mu \mathrm{m}$ and $326.0-342.7 \mu \mathrm{m}$, respectively. The mean surface area of the yellow cassava flour samples was thus larger than the white samples with about a difference of $89 \mu \mathrm{m}$ due to variation in the cultivar. The range of Dx10, Dx50 and Dx90 of the flour samples showed that the cassava flours have a combination of varying particle sizes which impacted the processing 
Table 2

Particle size distribution, bulk density and gelation capacity of cassava flour samples.

\begin{tabular}{|c|c|c|c|c|c|c|}
\hline & WFU0 & WFU5 & WFU10 & YFUO & YFU5 & YFU10 \\
\hline MeanVD $(\mu \mathrm{m})$ & $149.7^{\mathrm{a}} \pm 3.2$ & $149.0^{\mathrm{a}} \pm 9.2$ & $135.7^{\mathrm{a}} \pm 0.3$ & $338.3^{\mathrm{b}} \pm 8.2$ & $326.0^{\mathrm{b}} \pm 2.7$ & $342.7^{\mathrm{b}} \pm 6.5$ \\
\hline Dx10 VD $(\mu \mathrm{m})$ & $10.1^{\mathrm{a}} \pm 0.0$ & $9.5^{\mathrm{a}} \pm 0.0$ & $8.7^{\mathrm{a}} \pm 0.0$ & $33.8^{c} \pm 4.3$ & $24.6^{\mathrm{b}} \pm 0.6$ & $23.6^{\mathrm{b}} \pm 1.0$ \\
\hline Dx50 VD $(\mu \mathrm{m})$ & $52.7^{\mathrm{b}} \pm 0.1$ & $47.3^{\mathrm{ab}} \pm 1.3$ & $39.2^{\mathrm{a}} \pm 0.7$ & $304.3 \mathrm{~cd} \pm 7.7$ & $292.0^{c} \pm 2.1$ & $309.7^{\mathrm{d}} \pm 5.9$ \\
\hline Dx90 VD $(\mu \mathrm{m})$ & $430.3^{\mathrm{a}} \pm 7.4$ & $429.3^{\mathrm{a}} \pm 2.6$ & $399.0^{\mathrm{a}} \pm 2.7$ & $654.3^{\mathrm{b}} \pm 3.5$ & $647.0^{\mathrm{b}} \pm 3.8$ & $677.3^{b} \pm 12.8$ \\
\hline Mean SA $(\mu \mathrm{m})$ & $10.4^{\mathrm{a}} \pm 0.2$ & $10.0^{\mathrm{a}} \pm 0.1$ & $9.2^{\mathrm{a}} \pm 0.1$ & $99.4^{\mathrm{d}} \pm 3.1$ & $79.6^{c} \pm 1.1$ & $73.5^{\mathrm{b}} \pm 1.0$ \\
\hline Dx10 SA $(\mu \mathrm{m})$ & $0.2^{\mathrm{a}} \pm 0.0$ & $0.2^{\mathrm{a}} \pm 0.0$ & $0.2^{\mathrm{a}} \pm 0.0$ & $10.1^{\mathrm{d}} \pm 0.0$ & $5.9^{c} \pm 0.0$ & $3.5^{\mathrm{b}} \pm 0.0$ \\
\hline Dx50 SA $(\mu \mathrm{m})$ & $0.5^{\mathrm{a}} \pm 0.0$ & $0.5^{\mathrm{a}} \pm 0.0$ & $0.6^{\mathrm{a}} \pm 0.0$ & $20.2^{\mathrm{d}} \pm 0.2$ & $17.2^{\mathrm{c}} \pm 0.1$ & $15.1^{\mathrm{b}} \pm 0.1$ \\
\hline Dx90 SA $(\mu \mathrm{m})$ & $18.9^{\mathrm{a}} \pm 0.2$ & $18.5^{\mathrm{a}} \pm 0.2$ & $17.9^{\mathrm{a}} \pm 0.1$ & $315.0^{c} \pm 8.7$ & $268.3^{b} \pm 3.3$ & $259.0^{\mathrm{b}} \pm 3.8$ \\
\hline LBD (g/ml) & $0.41^{b} \pm 0.0$ & $0.39^{\mathrm{b}} \pm 0.0$ & $0.36^{\mathrm{a}} \pm 0.0$ & $0.47^{c} \pm 0.0$ & $0.45^{c} \pm 0.0$ & $0.46^{c} \pm 0.0$ \\
\hline PBD $(\mathrm{g} / \mathrm{ml})$ & $0.59^{\mathrm{ab}} \pm 0.0$ & $0.62^{\mathrm{b}} \pm 0.0$ & $0.59^{\mathrm{ab}} \pm 0.0$ & $0.55^{\mathrm{a}} \pm 0.0$ & $0.56^{\mathrm{a}} \pm 0.0$ & $0.56^{\mathrm{a}} \pm 0.0$ \\
\hline LGC (\%) & $12.67^{\mathrm{a}} \pm 0.2$ & $12.00^{\mathrm{a}} \pm 0.0$ & $15.33^{c} \pm 0.2$ & $12.00^{\mathrm{a}} \pm 0.0$ & $14.00^{\mathrm{b}} \pm 0.0$ & $16.00^{c} \pm 0.0$ \\
\hline
\end{tabular}

Results are presented as means \pm standard deviations $(n=3)$. Rows with the same superscript are not significantly different ( $\mathrm{p}<0.05$ ).

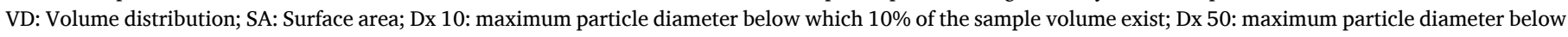

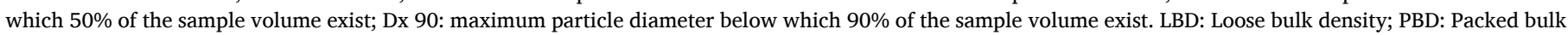
density; LGC: Least gelation concentration.

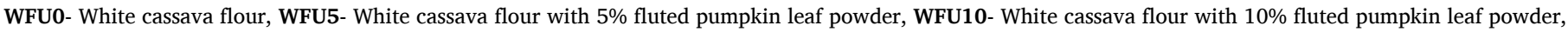

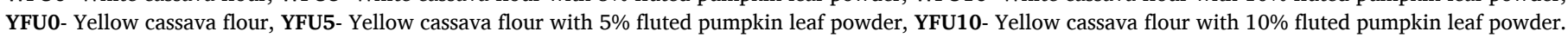

performance of the flours. This was in line with the findings of Chisenga et al. (2019) and Oladunmoye, Aworh, Maziya-Dixon, Erukainure, and Elemo (2014), which suggested that a decrease in particle sizes enhances hydration, thus increasing the solubility of flours.

Fluted pumpkin leaf addition decreased the mean volume distribution (4-9\%) and surface area (12-26\%) of the flour samples. The results also confirmed that yellow-fleshed cassava flours had a larger volume distribution than the white-fleshed cultivar, in line with the reports of Ayetigbo, Latif, Abass, and Müller (2018). The particle size influences starch behaviour; while lower onset gelatinisation temperatures, peak, final and hold viscosities with a decrease in particle sizes have also been reported (Chisenga et al., 2019; Ahmed et al., 2018). However, in a separate study, the protein content of the yellow cassava flours was found lower than wheat flour at $0.99-2.95 \mathrm{~g} / 100 \mathrm{~g}$ while the total dietary fibre was comparable at between 9.0 and $10.0 \mathrm{~g} / 100 \mathrm{~g}$ dry weight (Lawal, Talsma, Bakker, Fogliano, \& Linnemann, 2021).

\subsubsection{Colour measurement}

Colour is a critical quality attribute of pasta as it directly influences

Table 3

Colour measurement of flour and pasta samples.

\begin{tabular}{lrrr}
\hline Sample & \multicolumn{1}{c}{$\mathbf{L}^{*}$} & \multicolumn{1}{c}{$\mathbf{a}^{*}$} & \multicolumn{1}{c}{$\mathbf{b}^{*}$} \\
\hline WFU0 & $90.6^{\mathrm{l}} \pm 0.1$ & $0.7^{\mathrm{i}} \pm 0.0$ & $7.8^{\mathrm{a}} \pm 0.1$ \\
WFU5 & $76.2^{\mathrm{h}} \pm 0.3$ & $-4.4^{\mathrm{f}} \pm 0.1$ & $15.2^{\mathrm{de}} \pm 0.4$ \\
WFU10 & $71.2^{\mathrm{g}} \pm 0.0$ & $-5.8^{\mathrm{e}} \pm 0.0$ & $16.8^{\mathrm{f}} \pm 0.0$ \\
YFU0 & $89.7^{\mathrm{k}} \pm 0.0$ & $0.3^{\mathrm{h}} \pm 0.0$ & $11.4^{\mathrm{b}} \pm 0.0$ \\
YFU5 & $77.7^{\mathrm{i}} \pm 0.4$ & $-7.8^{\mathrm{b}} \pm 0.0$ & $11.7^{\mathrm{b}} \pm 0.1$ \\
YFU10 & $66.2^{\mathrm{e}} \pm 0.0$ & $-7.9^{\mathrm{a}} \pm 0.0$ & $16.6^{\mathrm{f}} \pm 0.2$ \\
WPU0 & $81.2^{\mathrm{j}} \pm 0.2$ & $1.5^{\mathrm{k}} \pm 0.1$ & $11.4^{\mathrm{b}} \pm 0.1$ \\
WPU5 & $61.7^{\mathrm{d}} \pm 0.1$ & $-0.1^{\mathrm{g}} \pm 0.0$ & $14.2^{\mathrm{c}} \pm 0.1$ \\
WPU10 & $53.4^{\mathrm{b}} \pm 0.0$ & $-0.2^{\mathrm{g}} \pm 0.0$ & $15.5^{\mathrm{e}} \pm 0.1$ \\
YPU0 & $70.0^{\mathrm{f}} \pm 0.7$ & $1.2^{\mathrm{j}} \pm 0.1$ & $15.1^{\mathrm{d}} \pm 0.3$ \\
YPU5 & $58.5^{\mathrm{c}} \pm 0.1$ & $-6.4^{\mathrm{d}} \pm 0.1$ & $26.2^{\mathrm{g}} \pm 0.1$ \\
YPU10 & $52.0^{\mathrm{a}} \pm 0.0$ & $-6.7^{\mathrm{c}} \pm 0.0$ & $27.1^{\mathrm{h}} \pm 0.1$ \\
\hline
\end{tabular}

The values are expressed as mean \pm standard deviation, $\mathrm{n}=3$ Columns with the same superscript are not significantly different $(\mathrm{p}<0.05)$.

L* scale: 0-50 (dark); 51-100 (light) a* scale: +ve value (red); -ve value (green) b* scale: +ve value (yellow); -ve value (blue).

WFU0- White cassava flour, WFU5- White cassava flour with $5 \%$ fluted pumpkin leaf powder, WFU10- White cassava flour with $10 \%$ fluted pumpkin leaf powder, YFU0- Yellow cassava flour, YFU5- Yellow cassava flour with 5\% fluted pumpkin leaf powder, YFU10- Yellow cassava flour with 10\% fluted pumpkin leaf powder, WPU0- White cassava pasta, WPU5- White cassava pasta fortified with $5 \%$ fluted pumpkin leaf powder, WPU10- White cassava pasta with fortified with $10 \%$ fluted pumpkin leaf powder, YPU0- Yellow cassava pasta, YPU5- Yellow cassava pasta fortified with 5\% fluted pumpkin leaf powder, YPU10- Yellow cassava pasta fortified with $10 \%$ fluted pumpkin leaf powder. the consumers' willingness to purchase (Zen et al., 2020). The colour profile of the flour and pasta samples is shown in Table 3, while the pictures of the samples are shown in Fig. 1. Cassava cultivar variation significantly influenced $L^{*}, a^{*}$ and $b^{*}$ values. $L^{*}$ values of the whole white cassava flour and pasta samples were 90.6 and 81.2, respectively, while the plain yellow cassava flour and pasta samples had $L^{*}$ values of 89.7 and 70 , respectively. These results were similar to previously reported lightness values of white and yellow cassava flours ranging from 83 to 96 (Rachman, Brennan, Morton, \& Brennan, 2019; Chisenga et al., 2019; Ayetigbo et al., 2018). The higher lightness in the white cassava products compared to those from the yellow cassava variety may be due to the difference in particle sizes (Table 2).

$\mathrm{L}^{*}$ values increase with decreasing particle size, as smaller particles have a larger surface area, enhancing light reflection (Oladunmoye et al., 2010). L* values of cassava-fluted pumpkin flour and pasta samples ranged from 66.2 to 77.7 and 52.0-61.7. As expected, lightness decreased significantly with the inclusion of fluted pumpkin leaf powder in the blends, suggesting that leaf powder addition impacts both cassava varieties products' lightness. Previous authors similarly recorded a decrease in lightness values of wheat pasta on green leaf powder inclusion because of the darkness of the enriching materials (Simonato et al., 2020; Zen et al., 2020). The decreased lightness from 66 to 90 in flour samples to $52-81$ in pasta shows that pasta production steps may modify the initial flour colours.

The $\mathrm{a}^{*}$ (red-green) values of the yellow cassava-fluted pumpkin flour blends were higher for the white cassava blends (Table 2). The yellow cassava flour and pasta samples also had higher $b^{*}$ values due to the yellow pigment in the biofortified cassava variety. The $b^{*}$ values of the fortified cassava-flour blends and pasta were high (above 11.0). The $a^{*}$ and $b *$ values of white and yellow cassava products were similar to previously reported values (Falade et al., 2019; Rachman et al., 2019; Ayetigbo et al., 2018). The addition of fluted pumpkin leaf powder resulted in products with negative $a^{*}$ and positive $b^{*}$, thus more pronounced greenness due to the chlorophyll present in the vegetable powder. The pasta greenness values are comparable with commercial spinach lasagne (a* of -5 to -6.5 ), as Suman et al. (2008), reported. The increased yellowness could be due to the presence of carotenoid pigments, such as $\beta$-carotene and xanthophyll (Zen et al., 2020). Increased pasta yellowness is perceived as a positive quality attribute as consumers prefer pasta with golden yellow colour (Sharma, Dar, Sharma, \& Singh, 2021; Mercier et al., 2016). Yellow cassava was also preferred to the white variety among consumers in Nigeria (Bechoff et al., 2018). Lawal, Fogliano, Rotte, Fagbemi, Dekker, and Linnemann (2021), similarly reported consumer acceptance of cassava pasta made with leafy vegetables and reported a more appreciable acceptance for yellow cassava pasta among the consumers. 


\subsection{Functional properties}

\subsubsection{Bulk densities of cassava flours}

The bulk density of flour is a critical quality factor as it provides information for storage, processing, and packaging (Chisenga et al., 2019). The values of the Loose bulk density (LBD) and Packed bulk density (PBD) of white cassava flour were lower than the yellow cassava flour $(0.41 \mathrm{~g} / \mathrm{ml}$ and $0.59 \mathrm{~g} / \mathrm{ml}$ vs $0.47 \mathrm{~g} / \mathrm{ml}$ and $0.55 \mathrm{~g} / \mathrm{ml}$, respectively), likely due to varietal differences and processing conditions. These figures are similar to previously reported results (Falade et al., 2019; Ajibola \& Olapade, 2017) for the white and yellow cultivars of cassava. A decrease in bulk density was observed with fluted pumpkin enrichment as the LBD and PBD of the cassava-fluted pumpkin flour blends ranged from 0.36 to $0.46 \mathrm{~g} / \mathrm{ml}$ and $0.56-0.62 \mathrm{~g} / \mathrm{ml}$, respectively (Table 2). The lower LBD on fluted pumpkin leaf enrichment could be due to lower carbohydrate content in the flour blends (Ocheme, Adedeji, Chinma, Yakubu, \& Ajibo, 2018; Alake et al., 2016). Chisenga et al. (2019) attributed the higher PBD compared to LBD to changes in geometry, size and surface properties of the flour which are influenced by the compacting forces. Previous authors similarly reported that, as particle size increased, bulk density decreased (Chisenga et al., 2019). The lower bulk densities of the investigated cassava flour blends in contrast to wheat flour could be seen as an advantage since it allows for high nutrient density and easy transportation (Ocheme et al., 2018; Alake et al., 2016).

\subsubsection{Gelation capacity}

The samples' least gelation concentration (LGC) ranged from $12 \%$ to $15 \%$ in the white cassava flours and $12-16 \%$ in the yellow cassava flour samples (Table 2). The least gelation concentration (LGC) indicates the minimum amount of flour needed to form a stable gel, and it serves as a measure of the flour's gelation capacity (Alake et al., 2016). Comparable cassava flour LGC of 12-14\% was previously reported (Ojo et al., 2017; Alake et al., 2016), while Chandra (2013), reported a lower LGC of 8 for wheat flour. The variation in the flour samples' gelation capacities could be due to interaction between their structural components such as carbohydrates, proteins, lipids, and amylose- amylopectin ratio (Alake et al., 2016; Chinma et al., 2013).

Gelation capacity decreased significantly with the addition of fluted pumpkin leaf since the higher the LGC, the lower the gelation capacity of the flour (Chandra et al., 2015; Chinma et al., 2013). The higher LGC in these blends suggests that they may have better capability to hold in food ingredients during preparation than pulse or legume flours whose surrounding protein matrix, as well as soluble and insoluble fibres, restrict starch gelatinisation (Noordraven, Bernaerts, Mommens, Hendrickx, \& Van Loey, 2021).

3.2.3. Water solubility, swelling power, water and oil absorption capacities

The water solubility (WS) of the yellow cassava flour and pasta samples was higher than the white variety's at $60^{\circ} \mathrm{C}(4.0-12.7 \%)$, but the reverse occurred at $90^{\circ} \mathrm{C}$ with the white cassava flour and pasta samples' solubility ranging from $10.7 \%$ to $26.7 \%$ while the yellow cassava flour and pasta samples had solubilities ranging from $3.0 \%$ to $8.0 \%$ (Table 4). Similar WS values of $4-32 \%$ and $2-24 \%$ were reported for white and yellow cassava flours, respectively (Ojo et al., 2017; Alake et al., 2016; Chinma et al., 2013; Oladunmoye et al., 2010). The water solubility of the flours is expected to increase at higher temperatures hence the evaluation at two temperatures 60 and $90^{\circ} \mathrm{C}$. The WS of the samples significantly increased with fluted pumpkin inclusion and increased temperature, similar to the results of Ojo et al. (2017). The decrease in yellow-cassava pasta samples' water solubility is desirable, suggesting lower cooking loss (Sharma et al., 2021). Swelling power (SP) decreased significantly on fluted pumpkin powder addition due to reduced starch content, higher fibre and weak internal forces between the starch granules (Gallo et al., 2020). This is likely because of the lack of formation of a network between proteins and starch, an indication of higher water absorption due to starch gelatinisation in the flour and pasta samples on heating. Swelling power is an important quality parameter in pasta products because it influences the volume and yield (Ibrahim \& Ani, 2018; Zen et al., 2020). Simonato et al. (2020), similarly reported a decrease in the swelling power of wheat pasta on the addition of moringa leaf powder. However, at $90^{\circ} \mathrm{C}$, fluted pumpkin inclusion had no significant effect on the investigated samples' swelling power, an indication of the effect of the insoluble fibres, suggesting that the added fluted pumpkin did not significantly interfere with starch gelatinisation. Comparable SP of $7-14 \%$ in white and yellow cassava flours were previously reported (Ayetigbo et al., 2018; Alake et al., 2016). The variation in swelling power between cassava cultivars may be due to their particle sizes, amylose and amylopectin contents, the interaction between non-starch components and starch molecules during gelatinisation (Awuchi et al., 2019).

Water holding capacity (WHC) influences the dough handling, volume and texture of the flour and pasta products (Sharma et al., 2021). WHC of the flours could be viewed as a measure of the optimum amount of water to be added before the dough becomes exceptionally sticky to handle (Awuchi et al., 2019). At $60{ }^{\circ} \mathrm{C}$, the WHC of the white cassava flour and pasta samples ranged from 6.2 to $7.0 \mathrm{~g} / \mathrm{g}$, while the yellow cassava flour and pasta samples had lower WHC ranging from 4.7 to

Table 4

Water solubility, swelling power, water holding capacity and oil absorption capacity of cassava-fluted pumpkin formulations.

\begin{tabular}{|c|c|c|c|c|c|c|c|}
\hline Sample & WS $60^{\circ} \mathrm{C}(\%)$ & WS $90^{\circ} \mathrm{C}(\%)$ & SP $60{ }^{\circ} \mathrm{C}(\%)$ & SP $90^{\circ} \mathrm{C}(\%)$ & WHC $60^{\circ} \mathrm{C}$ (g water/g sample) & WHC $90^{\circ} \mathrm{C}$ (g water/g sample) & OAC g oil/g sample \\
\hline WFUO & $3.7^{\mathrm{a}} \pm 0.6$ & $20.3^{\mathrm{d}} \pm 0.1$ & $6.4^{c} \pm 0.2$ & $7.2^{c} \pm 0.3$ & $6.2^{c} \pm 0.2$ & $5.8^{\mathrm{b}} \pm 0.2$ & $1.9^{\mathrm{b}} \pm 0.0$ \\
\hline WFU5 & $5.0^{\mathrm{bc}} \pm 0.0$ & $26.7^{\mathrm{e}} \pm 0.1$ & $6.8^{\mathrm{d}} \pm 0.3$ & $7.2^{c} \pm 0.2$ & $6.5^{\mathrm{d}} \pm 0.3$ & $5.3^{\mathrm{a}} \pm 0.3$ & $1.8^{\mathrm{b}} \pm 0.1$ \\
\hline WFU10 & $6.0^{\mathrm{c}} \pm 1.0$ & $22.7^{\mathrm{d}} \pm 0.2$ & $6.9^{\mathrm{d}} \pm 0.3$ & $7.8^{\mathrm{c}} \pm 0.1$ & $6.5^{\mathrm{d}} \pm 0.3$ & $6.1^{\mathrm{c}} \pm 0.0$ & $2.3^{\mathrm{b}} \pm 0.6$ \\
\hline YFUO & $4.0^{\mathrm{a}} \pm 0.0$ & $6.6^{\mathrm{b}} \pm 0.5$ & $7.3^{\mathrm{e}} \pm 0.1$ & $6.5^{\mathrm{b}} \pm 0.3$ & $7.0^{\mathrm{e}} \pm 0.1$ & $6.1^{c} \pm 0.3$ & $2.0^{\mathrm{b}} \pm 0.1$ \\
\hline YFU5 & $6.7^{\mathrm{cd}} \pm 0.6$ & $6.9^{\mathrm{b}} \pm 0.8$ & $6.4^{c} \pm 0.1$ & $6.6^{\mathrm{b}} \pm 0.5$ & $6.0^{\mathrm{b}} \pm 0.1$ & $6.2^{c} \pm 0.4$ & $2.0^{\mathrm{b}} \pm 0.1$ \\
\hline YFU10 & $12.7^{\mathrm{e}} \pm 0.5$ & $8.0^{\mathrm{b}} \pm 1.0$ & $5.7^{\mathrm{b}} \pm 0.2$ & $6.7^{b} \pm 0.6$ & $5.0^{\mathrm{a}} \pm 0.2$ & $6.1^{\mathrm{c}} \pm 0.5$ & $2.1^{\mathrm{b}} \pm 0.0$ \\
\hline WPUO & $2.3^{\mathrm{a}} \pm 0.7$ & $10.7^{\mathrm{c}} \pm 0.9$ & $7.1^{\mathrm{de}} \pm 0.1$ & $6.0^{\mathrm{a}} \pm 0.2$ & $7.0^{\mathrm{e}} \pm 0.0$ & $5.4^{\mathrm{ab}} \pm 0.2$ & $1.9^{\mathrm{b}} \pm 0.4$ \\
\hline WPU5 & $4.3^{\mathrm{b}} \pm 0.6$ & $14.7^{c} \pm 0.0$ & $6.6^{c} \pm 0.1$ & $6.2^{\mathrm{a}} \pm 0.3$ & $6.3^{c} \pm 0.1$ & $5.3^{\mathrm{ab}} \pm 0.4$ & $1.5^{\mathrm{a}} \pm 0.1$ \\
\hline WPU10 & $4.7^{b} \pm 0.7$ & $15.0^{c} \pm 0.5$ & $6.5^{c} \pm 0.1$ & $6.2^{\mathrm{a}} \pm 0.3$ & $6.2^{c} \pm 0.0$ & $5.2^{\mathrm{a}} \pm 0.2$ & $1.9^{b} \pm 0.5$ \\
\hline YPUO & $4.3^{b} \pm 0.6$ & $3.0^{\mathrm{a}} \pm 0.6$ & $5.9^{\mathrm{b}} \pm 0.4$ & $6.7^{\mathrm{b}} \pm 0.2$ & $5.7^{\mathrm{b}} \pm 0.3$ & $6.5^{\mathrm{d}} \pm 0.2$ & $1.9^{\mathrm{b}} \pm 0.2$ \\
\hline YPU5 & $5.7^{c} \pm 0.6$ & $4.0^{\mathrm{a}} \pm 0.6$ & $5.4^{\mathrm{a}} \pm 0.2$ & $6.2^{\mathrm{a}} \pm 0.2$ & $5.1^{\mathrm{a}} \pm 0.2$ & $6.0^{c} \pm 0.1$ & $1.6^{\mathrm{a}} \pm 0.1$ \\
\hline YPU10 & $7.0^{\mathrm{d}} \pm 0.6$ & $3.7^{\mathrm{a}} \pm 0.3$ & $5.1^{\mathrm{a}} \pm 0.3$ & $6.3^{\mathrm{a}} \pm 0.2$ & $4.7^{\mathrm{a}} \pm 0.3$ & $6.1^{c} \pm 0.2$ & $1.9^{\mathrm{b}} \pm 0.2$ \\
\hline
\end{tabular}

The values are expressed as mean \pm standard deviation, $\mathrm{n}=3$ Columns with the same superscript are not significantly different ( $\mathrm{p}=0.05$ ).

WS: Water solubility; SP: Swelling power; WAC: Water holding capacity; OAC: Oil absorption capacity.

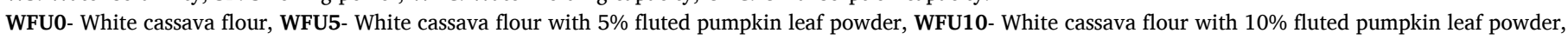

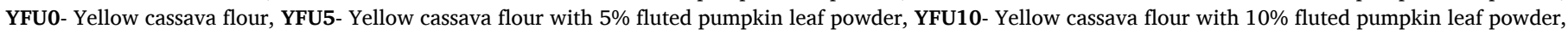

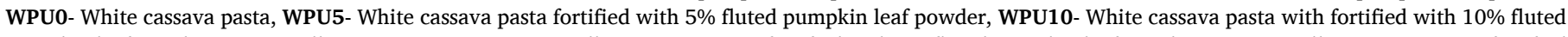

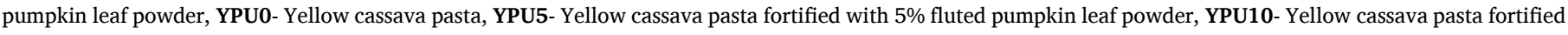
with $10 \%$ fluted pumpkin leaf powder. 
$7.0 \mathrm{~g} / \mathrm{g}$. At $90^{\circ} \mathrm{C}$, the WHC of the white cassava flour and pasta samples ranged from 5.2 to $5.8 \mathrm{~g} / \mathrm{g}$, while the yellow cassava flour and pasta samples had higher WHC ranging from 6.0 to $6.5 \mathrm{~g} / \mathrm{g}$. The higher WHC in the yellow cassava variety may be due to its higher amorphous amylose content (Ayetigbo et al., 2018), which may have more water binding sites (Ojo et al., 2017; Chandra et al., 2015). WHC of the pasta products studied was similar to that of wheat $(7.33 \mathrm{~g} / \mathrm{g})$, as reported by Ibrahim and Ani (2018) WHC decreased significantly on the addition of fluted pumpkin leaf, probably due to competition between entrapped soluble fibre particles and starch molecules for water. An unexpected decrease in WHC in some of the samples on the increase in temperature was observed. The higher temperature could result in higher kinetic energy, allowing increased interaction between the solutes and water. However, the temperature increase could have weakened the molecular bonds and starch network beyond a certain point, leading to leakage of the absorbed water; consequently, the observed lower WHC. The reduced WHC could be advantageous since an excess could lead to undesirably soft and brittle pasta (Ibrahim \& Ani, 2018).

The oil absorption capacity of the white cassava flour and pasta samples ranged from 1.5 to $2.3 \mathrm{~g} / \mathrm{g}$, while the yellow cassava flour and pasta samples had higher OAC ranging from 1.6 to $2.1 \mathrm{~g} / \mathrm{g}$. Previous authors similarly reported OAC ranging from 1 to $3 \mathrm{~g} / \mathrm{g}$ in white and yellow cassava flours (Falade et al., 2019; Ajibola \& Olapade, 2017).

Due to the protein content in fluted pumpkin leaf (Omimakinde et al., 2018), the OAC was expected to increase since proteins contain both hydrophilic and hydrophobic side chains; the non-polar side chains can interact with lipid chains, enhancing the oil absorption (Awuchi et al., 2019; Tharise et al., 2014). An interesting observation was made in the pasta samples as the OAC decreased significantly on $5 \%$ fluted pumpkin inclusion, followed by an increase at $10 \%$ fluted pumpkin leaf inclusion. The initial decrease at $5 \%$ leaf powder inclusion could be due to competition between the protein and other components.

Subsequently, at $10 \%$ inclusion, it could be that there was sufficient protein to allow for the non-polar chains to bind to the oil, thus increasing the oil absorption capacity. The higher OAC occurrence, at $10 \%$, could be due to the ease of oil penetration under this condition, where more lipophilic groups (more dry leaf powder) were available. The OAC of the formulated samples is advantageous because oil is commonly employed as an anti-stick agent during pasta preparation by many sub-African consumers (Ayetigbo et al., 2018). Additionally, oil enhances flavour retention and mouthfeel (Awuchi et al., 2019).

\subsubsection{Cooking properties (Optimum cooking time, weight gain and gruel solid loss)}

The optimum cooking time of the investigated cassava pasta samples was $5-11$ min while cooking times decreased significantly with fluted pumpkin addition (Fig. 2). Comparable cooking times of 5-9 min and 7-9 min have been reported for wheat and cassava-based pasta products, respectively (Odey \& Lee, 2020; Kaur, Shevkani, Katyal, Singh, Ahlawat, \& Singh, 2016). Previous authors have reported a similar trend of decreased cooking time of pasta on enrichment (Michalak-Majewska et al., 2020; Simonato et al., 2020; Sobota et al., 2020). A decrease in OCT could be due to the fibres in fluted pumpkin, which create interference in the structural starch network, thus facilitating water penetration and consequently, faster gelatinisation of the starch core (Simonato et al., 2020; Sobota et al., 2020). The lower starch content of the fortified pasta could also have influenced the OCT since gelatinisation of a lower amount of starch would have been needed. The shorter OCT in the fortified pasta is favourable since longer cooking times result in higher nutrient losses and increased energy use.

3.2.4.1. Weight gain. Weight gain (WG) of the cooked pasta samples, a measure of the water absorbed by the pasta during cooking ranged from $100 \%$ to $160 \%$ (Fig. 3). Inadequate water absorption results in harder pasta, while excess water absorption may lead to overly soft and sticky

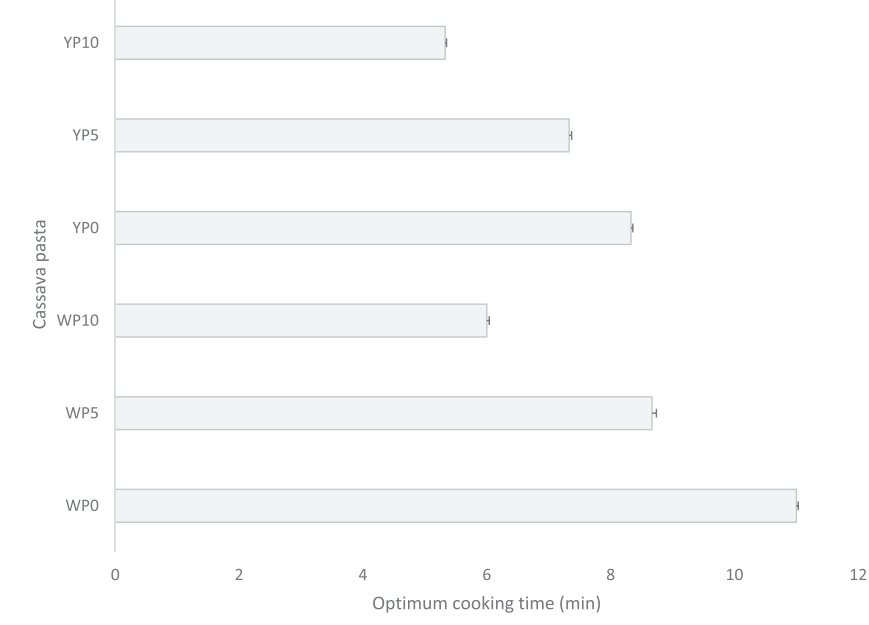

Fig. 2. Optimum cooking time of cooked cassava pasta samples. WPUO- White cassava pasta, WPU5- White cassava pasta fortified with $5 \%$ fluted pumpkin leaf powder, WPU10- White cassava pasta with fortified with $10 \%$ fluted pumpkin leaf powder, YPUO- Yellow cassava pasta, YPU5- Yellow cassava pasta fortified with $5 \%$ fluted pumpkin leaf powder, YPU10- Yellow cassava pasta fortified with $10 \%$ fluted pumpkin leaf powder.

pasta. The cooking weight gain in pasta products from wheat (100-195\%) and cassava (170-200\%) has been reported (Odey \& Lee, 2020; Gao et al., 2018). Yellow pasta had a higher WG than white pasta, similar to the WAC trend. An increase in cooking mass on the addition of fluted pumpkin powder may result from the interaction between the present fibres and starch matrix. The fibres could have weakened the starch network, resulting in better water diffusion and more water absorption (Panghal, Kaur, Janghu, Sharma, Sharma, \& Chhikara, 2019). The increase in weight gain was accompanied by a concomitant decrease in gruel solid loss, signifying the pasta products' excellent cooking quality. According to Kruger et al. (1996), a minimum weight gain of $100 \%$ is expected in high-quality pasta products. Thus, all formulated pasta products in the present study showed high quality in this parameter. The increased weight gain due to water absorption indicates that the pasta could be more effective in providing a feeling of satiety to consumers and making the pasta easier to chew (Michalak-Majewska et al. 2020).

3.2.4.2. Gruel solid loss. Gruel solid loss (GSL) of the cooked pasta samples ranged between $0.8 \%$ and $2.6 \%$ (Fig. 3). Gruel solid loss (GSL) is associated with the leakage of soluble starch and non-starch components into the cooking water, which results in an unpleasant sticky texture (Zen et al., 2020). It is a measure of the pasta's resistance to structural disintegration during cooking, thus an important quality attribute of cooked pasta. Odey and Lee (2020) and Gao et al. (2018), similarly reported GSL of $0.6-1.2 \%$ in cassava pasta products. Although no significant difference between the white and yellow cassava varieties was observed, yellow cassava pasta samples showed a tendency to have lower gruel solid losses than the white variety. The cooking losses of the formulated pasta samples were lower than GSL of $2.7-7 \%$ reported for wheat pasta products (Sharma et al., 2021; Kaur et al., 2016). Maximum acceptable cooking loss has been defined as $\leq 8 \%$ (Kruger et al., 1996); thus, the formulated pasta in this study showed acceptable cooking qualities.

\subsection{Hardness of gel and pasta}

The effect of leaf powder addition on the textural properties of the pasta samples is indicated by the hardness of the flour gels and pasta samples, as shown in Table 5. Hardness ranged from 0.8 to $1.8 \mathrm{~N}$ in the gel samples and 10.4-13.2 N in the cooked pasta samples. Gel and pasta 

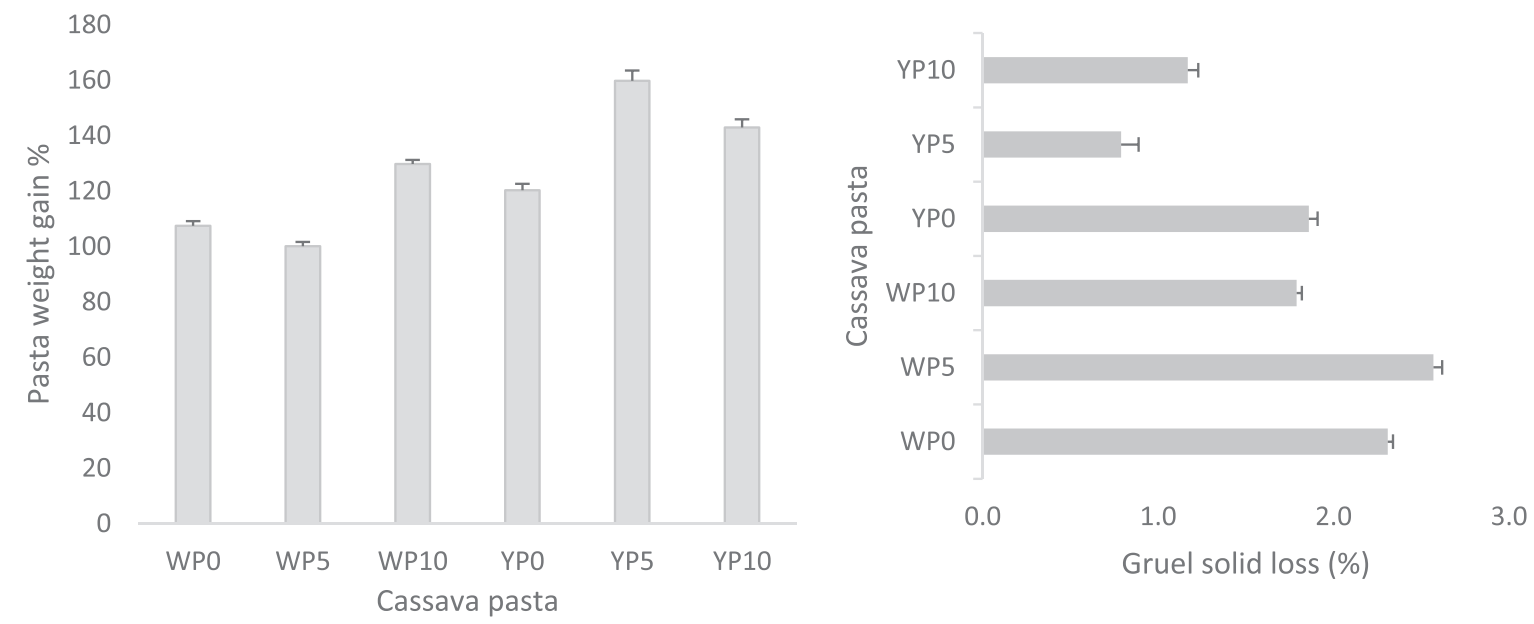

Fig. 3. Cooking properties (weight gain and gruel solid loss) of cooked cassava pasta samples. WPUO- White cassava pasta, WPU5- White cassava pasta fortified with $5 \%$ fluted pumpkin leaf powder, WPU10- White cassava pasta with fortified with 10\% fluted pumpkin leaf powder, YPU0- Yellow cassava pasta, YPU5- Yellow cassava pasta fortified with $5 \%$ fluted pumpkin leaf powder, YPU10- Yellow cassava pasta fortified with 10\% fluted pumpkin leaf powder.

Table 5

Pasting properties of cassava flour and pasta.

\begin{tabular}{|c|c|c|c|c|c|c|c|c|}
\hline Sample & $\begin{array}{l}\text { Peak viscosity } \\
\text { (cP) }\end{array}$ & $\begin{array}{l}\text { Hold Viscosity } \\
\text { (cP) }\end{array}$ & $\begin{array}{l}\text { Breakdown } \\
\text { viscosity }(\mathrm{cP})\end{array}$ & $\begin{array}{l}\text { Final Viscosity } \\
\text { (cP) }\end{array}$ & $\begin{array}{l}\text { Setback viscosity } \\
\text { (cP) }\end{array}$ & $\begin{array}{l}\text { Peak Time } \\
(\mathrm{min})\end{array}$ & $\begin{array}{l}\text { Pasting Temp. } \\
\left({ }^{\circ} \mathrm{C}\right)\end{array}$ & $\begin{array}{l}\text { Hardness } \\
\text { (N) }\end{array}$ \\
\hline WFUO & $1858^{\mathrm{d}} \pm 57.8$ & $1025^{c} \pm 28.1$ & $833^{b} \pm 42.1$ & $1354^{c} \pm 26.6$ & $329^{c} \pm 10.4$ & $4.69^{c} \pm 0.1$ & $74.3^{\mathrm{b}} \pm 0.1$ & $1.7^{\mathrm{a}} \pm 0.7$ \\
\hline WFU5 & $1757^{\mathrm{cd}} \pm 2.3$ & $823^{a} \pm 8.7$ & $934^{c} \pm 7.0$ & $1091^{\mathrm{a}} \pm 1.3$ & $268^{a} \pm 3.7$ & $4.41^{\mathrm{a}} \pm 0.0$ & $74.9^{b} \pm 0.4$ & $1.7^{\mathrm{a}} \pm 1.0$ \\
\hline WFU10 & $1672^{\mathrm{bc}} \pm 12.4$ & $747^{\mathrm{a}} \pm 7.5$ & $924^{c} \pm 10.2$ & $1006^{\mathrm{a}} \pm 3.8$ & $258^{\mathrm{a}} \pm 4.1$ & $4.21^{\mathrm{a}} \pm 0.0$ & $74.9^{b} \pm 0.5$ & $0.8^{\mathrm{a}} \pm 0.2$ \\
\hline YFUO & $2899^{g} \pm 63.5$ & $1752^{g} \pm 6.5$ & $1148^{\mathrm{d}} \pm 25.1$ & $2530^{\mathrm{h}} \pm 43.0$ & $778^{\mathrm{h}} \pm 4.6$ & $4.62^{b c} \pm 0.1$ & $74.9^{\mathrm{b}} \pm 0.5$ & $1.7^{\mathrm{a}} \pm 0.6$ \\
\hline YFU5 & $2631^{\mathrm{f}} \pm 30.1$ & $1508^{\mathrm{e}} \pm 14.5$ & $1124^{\mathrm{d}} \pm 21.9$ & $2194^{\mathrm{f}} \pm 14.8$ & $687^{\mathrm{f}} \pm 8.7$ & $4.47^{\mathrm{ab}} \pm 0.1$ & $74.6^{b} \pm 0.5$ & $1.8^{\mathrm{a}} \pm 0.4$ \\
\hline YFU10 & $2386^{\mathrm{e}} \pm 4.7$ & $1368^{\mathrm{d}} \pm 24.4$ & $1017^{c} \pm 17.1$ & $2000^{\mathrm{e}} \pm 9.1$ & $632^{\mathrm{e}} \pm 11.1$ & $4.36^{\mathrm{a}} \pm 0.0$ & $74.9^{\mathrm{b}} \pm 0.5$ & $1.4^{\mathrm{a}} \pm 1.0$ \\
\hline WPUO & $2722^{\mathrm{f}} \pm 32.5$ & $1414^{\mathrm{d}} \pm 7.7$ & $1309^{\mathrm{e}} \pm 25.0$ & $1867^{\mathrm{d}} \pm 8.2$ & $453^{d} \pm 9.3$ & $4.56^{\mathrm{b}} \pm 0.1$ & $73.8^{a} \pm 0.5$ & $12.2^{\mathrm{a}} \pm 0.7$ \\
\hline WPU5 & $1610^{b} \pm 17.5$ & $933^{\mathrm{b}} \pm 6.1$ & $677^{\mathrm{a}} \pm 11.8$ & $1230^{\mathrm{b}} \pm 11.0$ & $297^{b} \pm 4.9$ & $4.36^{\mathrm{a}} \pm 0.0$ & $74.0^{\mathrm{b}} \pm 0.5$ & $11.6^{\mathrm{a}} \pm 1.0$ \\
\hline WPU10 & $1373^{\mathrm{a}} \pm 15.3$ & $769^{a} \pm 7.8$ & $604^{\mathrm{a}} \pm 9.5$ & $1030^{\mathrm{a}} \pm 13.8$ & $261^{\mathrm{a}} \pm 6.3$ & $4.43^{\mathrm{a}} \pm 0.0$ & $74.8^{\mathrm{b}} \pm 0.5$ & $11.6^{\mathrm{a}} \pm 0.5$ \\
\hline YPU0 & $2841^{g} \pm 19.4$ & $1865^{\mathrm{h}} \pm 17.5$ & $976^{c} \pm 7.3$ & $2782^{i} \pm 22.7$ & $917^{\mathrm{i}} \pm 8.5$ & $4.63^{b c} \pm 0.0$ & $73.1^{a} \pm 0.4$ & $13.2^{\mathrm{a}} \pm 0.8$ \\
\hline YPU5 & $2844^{g} \pm 59.8$ & $1658^{\mathrm{f}} \pm 27.0$ & $1187^{\mathrm{d}} \pm 33.8$ & $2383^{g} \pm 31.2$ & $725^{g} \pm 7.0$ & $4.58^{\mathrm{b}} \pm 0.1$ & $74.0^{\mathrm{b}} \pm 0.5$ & $11.8^{\mathrm{a}} \pm 1.1$ \\
\hline YPU10 & $2674^{\mathrm{f}} \pm 37.1$ & $1547^{\mathrm{e}} \pm 21.3$ & $1127^{\mathrm{d}} \pm 15.9$ & $2223^{\mathrm{f}} \pm 24.5$ & $676^{f} \pm 3.2$ & $4.54^{\mathrm{b}} \pm 0.0$ & $74.0^{\mathrm{b}} \pm 0.4$ & $10.4^{\mathrm{a}} \pm 0.9$ \\
\hline
\end{tabular}

The values are expressed as mean \pm standard deviation, $\mathrm{n}=3$ Columns with the same superscript are not significantly different ( $\mathrm{p}=0.05$ ).

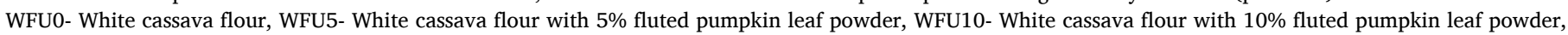

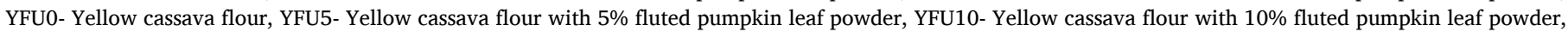

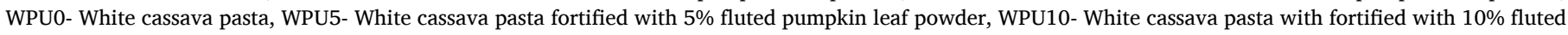

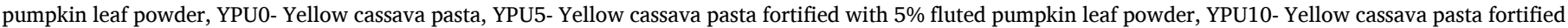
with $10 \%$ fluted pumpkin leaf powder.

hardness decreased on the inclusion of fluted pumpkin leaf due to the lower starch content, thus less retrogradation during gel formation and the emulsifying effect of the protein and fibre on the dough. Fluted pumpkin leaves have been reported to act as an emulsifier in food due to their high protein and fibre content which aids the reduction of hardness (Gbadamosi, Famuwagun, \& Nnamezie, 2018; Sobowale et al., 2011). This observation was confirmed by the weight gain of cooked pasta due to water absorption, which also increased with fluted pumpkin leaf inclusion (Fig. 3). The samples' hardness indicates the amount of compression force that the product can withstand before mechanical disintegration (Ayetigbo et al., 2018). Simonato et al. (2020), also reported a decrease in pasta hardness on the addition of moringa leaf powder to wheat pasta. Cassava-fluted pumpkin blends contained a higher proportion of fibre, so it holds a large amount of water and interrupts the starch matrix, resulting in a weak gel and pasta network. The reported firmness of wheat (43 N) and potato noodles (29-31 N) by Kaur et al. (2016), were higher than the investigated pasta. The firmness of cooked gluten-free pasta is lower than high-gluten pasta due to weaker dough matrix, starch leaching and water absorption (Zen et al., 2020).

\subsection{Impact of leaf powder addition on pasting properties of cassava pasta}

The influence of fluted pumpkin leaf powder inclusion on the pasting properties: peak viscosity, trough, breakdown, final viscosity, setback, peak time and pasting temperature of the cassava pasta is shown in Table 5. Results showed that the peak viscosity of white and yellow cassava samples decreased with increasing fluted pumpkin leaf addition from 1373 to $1858 \mathrm{cP}$ and $2386-2899 \mathrm{cP}$, respectively. The decrease in peak viscosity on fluted pumpkin inclusion could be due to lower starch content and dilution of the starch network by fibre particles (Panghal et al., 2019). Peak viscosity (PV) indicates the thickening power of the flour and potential viscous load encountered during mixing (Alake et al., 2016; Chinma et al., 2013). The Hold viscosity (HV) of white and yellow cassava samples ranged from 747 to $1414 \mathrm{cP}$ and $1368-1865 \mathrm{cP}$, respectively. Yellow cassava flour and pasta samples had significantly higher HV than the white variety. The higher peak, final and hold viscosities of the yellow-cassava flour could result from its larger particle size and higher starch content (Ahmed et al., 2018). The lower HV on the addition of fluted pumpkin leaf was probably due to the reduced starch content (Alake et al., 2016). HV thus represents the ability of the sample to withstand breakdown during cooling (Ayetigbo et al., 2018), an indication of the better stability of the fortified cassava pasta. 
The breakdown viscosity (BV) of white and yellow cassava samples was $833-1309 \mathrm{cP}$ and $1017-1187 \mathrm{cP}$. BV measures the flour and pasta's disintegration on heating (Panghal et al., 2019). As expected, the yellow cassava products' breakdown viscosities were higher since the breakdown viscosity is related to the peak viscosity. Low breakdown viscosities of the fluted pumpkin-fortified samples indicate the products' increased capacity to withstand breakdown during cooking. Previous authors confirmed that the higher the breakdown viscosity, the lower the starch stability during heating and mechanical stress (Ocheme et al., 2018; Alake et al., 2016). Increased thermal stability in the fluted pumpkin-fortified products could be due to fibres' hydrophilic nature, facilitating interaction between starch-protein-water molecules (Panghal et al., 2019).

The final viscosity (FV) of the yellow cassava samples were significantly higher than the white (2000-2782 cP vs 1006-1867 cP, respectively) with the yellow unfortified pasta (YPU0) having the highest value. FV indicates the sample's ability to form a gel network after cooking and cooling due to the re-association of the starch molecules (Sharma et al., 2021). High final viscosity is desirable in pasta since it requires an increase in cooking volume (Falade et al., 2019).

Setback viscosity (SV) is a measure of the retrogradation tendency of the flour and pasta samples (Falade et al., 2019). White cassava flour and pasta samples' setback viscosities ranged from 258 to $453 \mathrm{cP}$, while yellow cassava flour and pasta samples had SV ranging from 632 to $917 \mathrm{cP}$. Similar to the previously described viscosities, yellow cassava flour and pasta samples had significantly higher SV than the white variety. SV also decreased significantly on the addition of fluted pumpkin leaf, which indicates a higher tendency of retrogradation of the starch (Ojo et al., 2017; Tharise et al., 2014). The peak time indicates the cooking time of the products. The flour and pasta samples' peak time ranged from 4 to $5 \mathrm{~min}$ (Table 5). Peak times of 4-6 min in cassava flour blends have been reported (Ajibola \& Olapade, 2017; Ojo et al., 2017). Peak time decreased significantly on 5\% fluted pumpkin leaf inclusion, which is favourable since longer peak times could indicate additional production costs. The pasting temperature of the cassava samples ranged from 73.1 to $74.9^{\circ} \mathrm{C}$. Similar pasting temperatures of $70-76^{\circ} \mathrm{C}$ in white and yellow cassava products have been recorded (Odey \& Lee, 2020; Ayetigbo et al., 2018). Pasting temperature represents the minimum temperature required to gelatinise or cook the flour and pasta samples (Alamu et al., 2017). Similar to gelatinisation temperatures, the pasting temperatures increased with fluted pumpkin inclusion. A previous report noted that pasting and gelatinisation temperatures increased with a decrease in starch content (Chandra et al., 2015). Considering that wheat had a higher pasting temperature of $77^{\circ} \mathrm{C}$ (Tharise et al., 2014), the production of the fortified cassava products may require lower energy costs. Pasting properties reflect the flour and pasta behaviour under varying shear stress and temperatures (Ayetigbo et al., 2018). Wheat flour has been reported to have lower viscosities and higher pasting temperature (Oladunmoye et al., 2014; Tharise et al., 2014) than the examined cassava flours. Increased pasting properties in the pasta samples indicate that the starch granules retained their structure during extrusion and heating (Leonel et al., 2011).

\subsection{Thermal properties}

Thermal properties, otherwise known as gelatinisation of starch (Tonset, Tpeak, Tend and enthalpy) were evaluated for all the samples (Fig. 4). The onset temperature (Tonset) ranged from 65.8 to $67.7^{\circ} \mathrm{C}$, Peak temperature (Tpeak) from $68.3^{\circ}$ to $70^{\circ} \mathrm{C}$, while cease/end temperature Tend ranged from $79.9^{\circ}$ to $82.4^{\circ} \mathrm{C}$. The gelatinisation enthalpy ranged from 8.7 to $12.7 \mathrm{~J} / \mathrm{g}$. Similar Tonset $\left(63-66{ }^{\circ} \mathrm{C}\right)$, Tpeak $\left(68.3-70^{\circ} \mathrm{C}\right)$, Tend $\left(74.4^{\circ} \mathrm{C}\right)$ and enthalpy $(9-14 \mathrm{~J} / \mathrm{g})$ of white and yellow cassava have been reported by other authors (Ayetigbo et al., 2018; Leonel et al., 2011). Yellow cassava flour and pasta samples had higher gelatinisation temperatures than white cassava-based samples, probably due to their larger particle size distribution (Ahmed et al., 2018). The increase in gelatinisation transition temperatures on fluted pumpkin leaf addition may be due to the samples' lower starch content (Chandra et al., 2015). Fluted pumpkin leaf-fortified formulations expectedly had lower starch contents; consequently, the lower enthalpies indicate that less energy was required to break down the starch structures. Literature also agrees that enthalpy decreases with a longer cooking time (Lu et al., 2020; Lionel et al., 2011). In comparison, wheat flour reportedly had Tonset, Tpeak, Tend and enthalpies in the range of 57.4-64.2 ${ }^{\circ} \mathrm{C}, 60.9-67.1^{\circ} \mathrm{C}, 64.3-70.1{ }^{\circ} \mathrm{C}$ and $3.2-8.4 \mathrm{~J} / \mathrm{g}$, respectively (Kaur et al., 2016). The lower gelatinisation characteristics of wheat than cassava may be due to its lower starch content, proteins and lipids, as well as particle sizes (Ahmed et al., 2019; Kaur et al., 2016).

\subsection{Sensory perception of pasta}

In most of the organoleptic attributes studied as shown in Fig. 5, the yellow cassava pasta was preferred to the white cassava pasta (score 6.6). The colour likability and firmness scores of the pasta samples
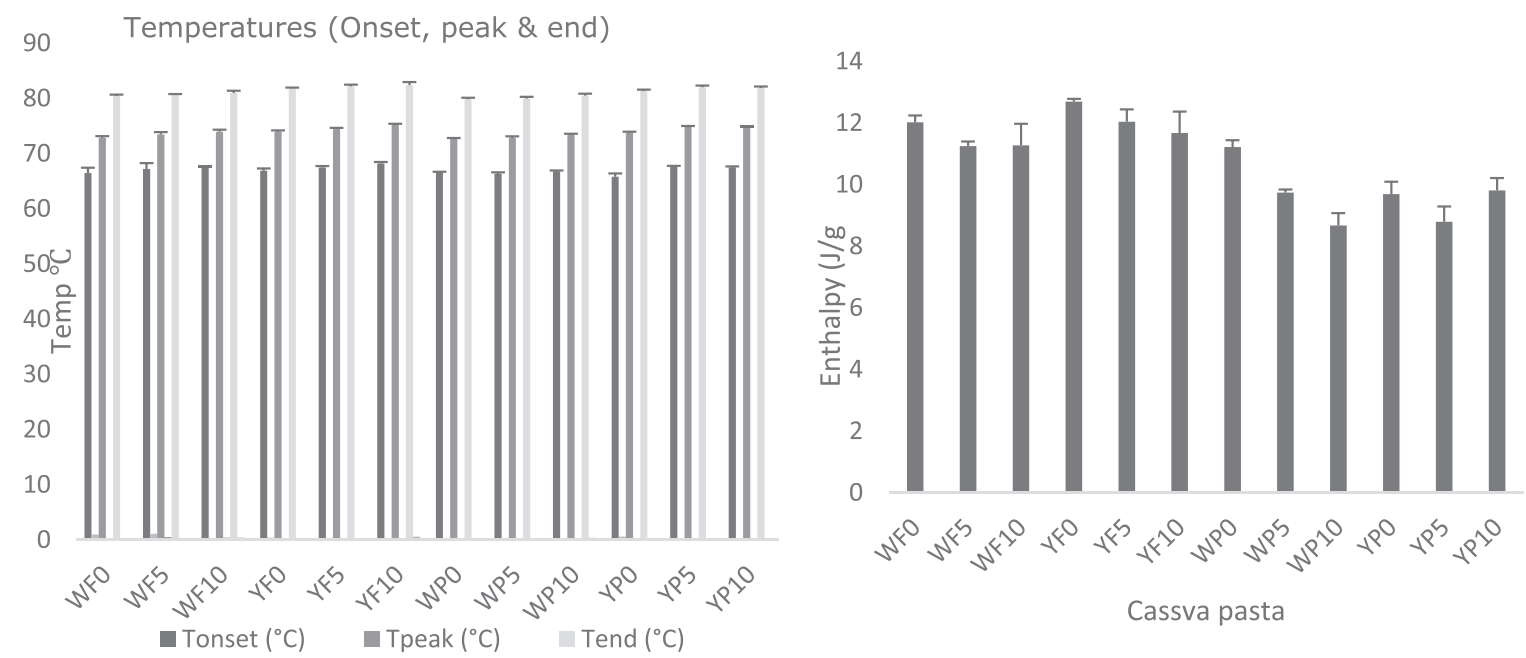

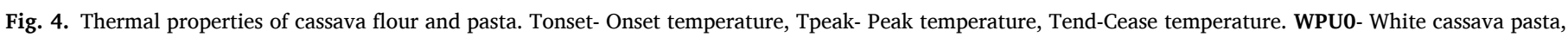

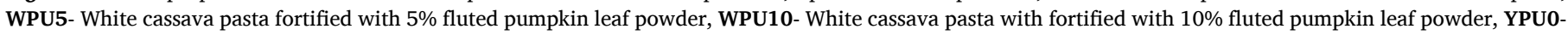

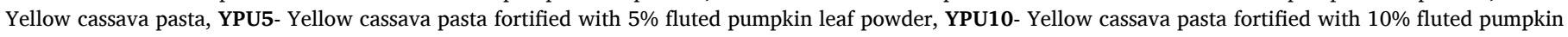
leaf powder. 


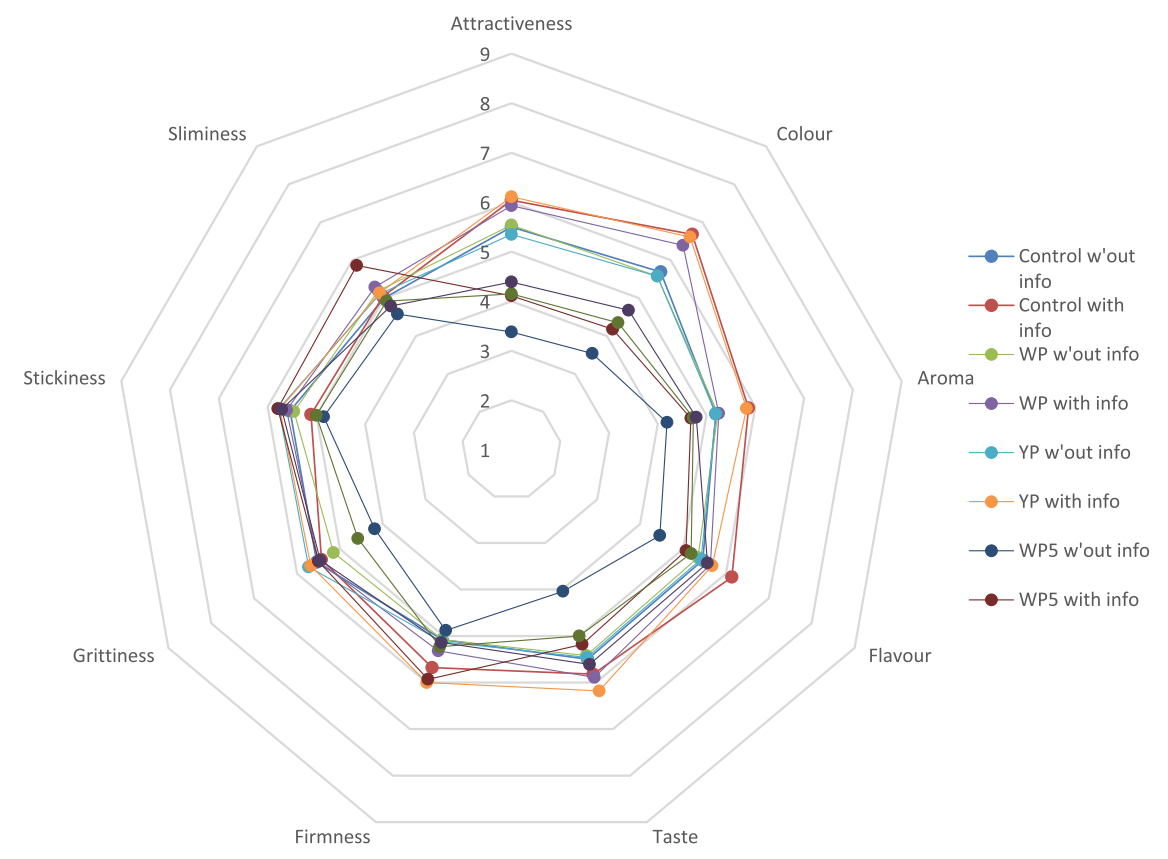

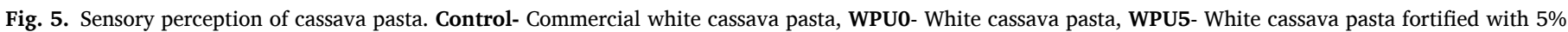
fluted pumpkin leaf powder, YPU0- Yellow cassava pasta, YPU5- Yellow cassava pasta fortified with 5\% fluted pumpkin leaf powder.

however decreased significantly on fluted pumpkin leaf addition. A similar decrease in acceptability of pasta fortified with vegetables was reported by Simonato et al. (2020), for wheat pasta fortified with Moringa oleifera L. leaf powder and Sato, Cilli, de Oliviera, Maciel, Venturini, and Yoshida (2019), for wheat pasta fortified with dried leaves of Pereskia aculeata Miller. Ayetigbo et al. (2018), also observed that yellow-flesh cassava was perceived as more attractive than white-flesh cassava. Yellow pasta without leaf addition (YPUO) was thus rated best in overall acceptability. Furthermore, the provision of nutritional information about the samples also boosted the overall acceptability and likability scores of the pasta, an indication that consumers may be more willing to purchase unfamiliar products perceived as more healthy. Similarly, Sato et al. (2019), suggested that although there is an increased market for healthier food products, information on new ingredients and healthy products should be provided to the consumers to enhance acceptance.

\section{Conclusion and recommendation}

The fortification of cassava pasta with fluted pumpkin leaf powder provided some beneficial effects to the techno-functional properties but also downsides particularly in sensory perception, compared to traditional wheat pasta. Fluted pumpkin-fortified pasta had lower pasting temperatures $\left(73.1-74.9^{\circ} \mathrm{C}\right.$ ) and may require lower energy costs than the wheat pasta with a pasting temperature of $77^{\circ} \mathrm{C}$. Interestingly, the fluted pumpkin leaf addition improved the cooking qualities of the cassava pasta, which was not the case observed for vegetable addition to wheat pasta. This is likely due to the absence of a gluten protein network, making the cassava matrix more suitable to incorporate vegetable materials without changing its properties. The addition of fluted pumpkin leaf powder expectedly impacted the colour parameters of developed pasta significantly. Yellow cassava flour had higher pasting viscosities and larger particle size distribution, enabling its suitability in pasta production. The addition of fluted pumpkin also resulted in a decrease in the hardness and cooking quality of pasta samples. To improve the texture of fluted pumpkin-fortified pasta, process modifications such as pre-gelatinisation, use of hydrocolloids, hot extrusion or extrusion with smaller dies are recommended. In future studies, we will extend this novel work by evaluating the physicochemical attributes and digestibility of the newly developed cassava-fluted pumpkin leaf pasta.

\section{Author contribution}

All authors provided feedback on the manuscript and approved the submitted version.

\section{Declaration of Competing Interest}

The authors declare that they have no known competing financial interests or personal relationships that could have appeared to influence the work reported in this paper.

\section{Acknowledgements}

This study was supported financially by the Tertiary Education Trust Fund (TETFund) of Nigeria and the graduate school VLAG, Wageningen University and Research, Netherlands. The staff of Unifarm, Wageningen University and Research are appreciated for the cultivation of the vegetables and the staff of the International Institute of Tropical Agriculture (IITA), Mr. Peter Iluebbey and Clara Alajo for the provision of the yellow cassava.

\section{References}

Ahmed, J., Thomas, L., \& Arfat, Y. (2019). Functional, rheological, microstructural and antioxidant properties of quinoa flour in dispersions as influenced by particle size. Food Research International, 116, 302-311. https://doi.org/10.1016/j. foodres.2018.08.039

Ajibola, G. O., \& Olapade, A. A. (2017). Effects of drying methods on the nutritional quality of provitamin A Cassava (Manihot esculenta Crantz) flours. Annals Food Science and Technology, 8(3), 355-363.

Alake, O. O, Babajide, J. M, Adebowale, A. A, \& Adebisi, M. A (2016). Evaluation of physico-chemical properties and sensory attributes of cassava enriched custard powder. Cogent Food Agric., 2(1). https://doi.org/10.1080/ 23311932.2016.1246116. In press.

Alamu, E. O., Maziya-Dixon, B., \& Dixon, A. G. (2017). Evaluation of proximate composition and pasting properties of high-quality cassava flour (HQCF) from cassava genotypes (Manihot esculenta Crantz) of $\beta$-carotene-enriched roots. LWTFood Science and Technology, 86(464), 501-506. https://doi.org/10.1016/j. lwt.2017.08.040

Aworh, C. O. (2015). Promoting food security and enhancing Nigeria's small farmers' income through value-added processing of lesser-known and under-utilized 
indigenous fruits and vegetables. Food Research International, 76, 986-991. https:// doi.org/10.1016/j.foodres.2015.06.003

Awuchi, C., Igwe, V., \& Echeta, C. (2019). The functional properties of foods and flours. International Journal of Advanced Academic Research Sciences, Technology and Engineering, 5(11), 139-160.

Ayetigbo, O., Latif, S., Abass, A., \& Müller, J. (2018). Comparing characteristics of root, flour and starch of biofortified yellow-flesh and white-flesh cassava variants, and sustainability considerations: a review. Sustainability, 10(9). https://doi.org/ 10.3390/su10093089

Baraheng, S. \& Karrila, T. (2019). Chemical and functional properties of durian (Durio zibethinus Murr.) seed flour and starch Food Bio, 30,100412-100412. 〈https://doi org /10.1016/j.fbio.2019.100412).

Bechoff, A., Chijioke, U., Westby, A., \& Tomlins, K. I. (2018). 'Yellow is good for you': consumer perception and acceptability of fortified and biofortified cassava products. PLOS One, 13(9), Article e0203421. https://doi.org/10.1371/journal.pone.0203421

Bouis, H. E., \& Saltzman, A. (2017). Improving nutrition through biofortification: a review of evidence from HarvestPlus, 2003 through 2016. Global Food Security, 12, 49-58.

Chandra, S. (2013). Assessment of functional properties of different flours. African Journal of Agricultural Research, 8(38), 4849-4852. https://doi.org/10.5897/ AJAR2013.6905

Chandra, S., Singh, S., \& Kumari, D. (2015). Evaluation of functional properties of composite flours and sensorial attributes of composite flour biscuits. Journal of Food Science and Technology, 52(6), 3681-3688. https://doi.org/10.1007/s13197-0141427-2

Chinma, C. E., Ariahu, C. C., \& Abu, J. O. (2013). Chemical composition, functional and pasting properties of cassava starch and soy protein concentrate blends. Journal of Food Science and Technology, 50(6), 1179-1185. https://doi.org/10.1007/s13197011-0451-8

Chisenga, S. C., Workneh, T. S., Bultosa, G., \& Laing, M. (2019). Proximate composition, cyanide contents, and particle size distribution of cassava flour from cassava varieties in Zambia. AIMS 486 Agriculture and Food, 4(4), 869-891. https://doi.org/ 10.3934/agrfood.2019.4.869

Costa, G. M., Paula, M. M., Costa, G. N., Esmerino, E. A., Silva, R., Freitas, M. Q., Pimentel, T. C. (2020). Preferred attribute elicitation methodology compared to conventional descriptive analysis: a study using probiotic yoghurt sweetened with xylitol and added with prebiotic components. Journal of Sensory Studies, 35(6). https://doi.org/10.1111/joss.12602

Duta, D. E., Culetu, A., \& Sozer, N. (2019). Effect of dry fractionated hybrid protein ingredients on $Q$ the structural, textural, thermal and sensory properties of glutenfree oat and faba pasta. International Journal of Food Science and Technology, 54(12), 3205-3215. https://doi.org/10.1111/ijfs.14297

Eyinla, T. E., Maziya-Dixon, B., Alamu, O. E., \& Sanusi, R. A. (2019). Retention of provitamin a content in products from new biofortified cassava varieties. Foods, 8(5), 177. https://doi.org/10.3390/foods8050177

Falade, K., Ibanga-Bamijoko, B., \& Ayetigbo, O. E. (2019). Comparing properties of starch and flour of yellow-flesh cassava cultivars and effects of modifications on properties of their starch. Journal of Food Measurement and Characterization, 1-13. https://doi.org/10.1007/s11694-019-00178-5

Gallo, V., Romano, A., \& Masi, P. (2020). Does the presence of fibres affect the microstructure and in vitro starch digestibility of commercial Italian pasta? Food Structure, 24, Article 100139. https://doi.org/10.1016/j.foostr.2020.100139

Gao, Y., Janes, M. E., Chaiya, B., Brennan, M. A., Brennan, C. S., \& Prinyawiwatkul, W. (2018). Gluten-free bakery and pasta products: prevalence and quality improvement. International Journal of Food Science \& Technology, 53(1), 19-32. https://doi.org/ 10.1111/ijfs. 13505

Gbadamosi, S. O., Famuwagun, A. A., \& Nnamezie, A. A. (2018). Effects of blanching with chemical preservatives on functional and antioxidant properties of fluted pumpkin (Telferia occidentalis) leaf. Nigerian Food Journal, 36(1), 45-57.

Gegios, A., Amthor, R., Maziya-Dixon, B., Egesi, C., Mallowa, S., Nungo, R., Manary, M. J. (2010). Children consuming Cassava as a staple food is at risk for inadequate zinc, iron, and vitamin A intake. Plant Foods for Human Nutrition, 65(1), 64-70. https://doi.org/10.1007/s11130-010-0157-5

Ibrahim, D. G., \& Ani, J. (2018). Evaluation of the nutritional and functional properties of Talia made from wheat/sorghum flour blends. Journal of Tropical Agriculture, Food, Environment and Extension, 17(2), 1-8.

Ilona, P., Bouis, H. E., Palenberg, M., Moursi, M., \& Oparinde, A. (2017). Vitamin A cassava in Nigeria: crop development and delivery. African Journal of Food, Agriculture, Nutrition and Development, 17(02), 12000-12025. https://doi.org/ 10.18697/ajfand.78. HarvestPlus09

International Pasta Organization (2020). 〈https://internationalpasta.org/about-ipo/〉.

Kaur, A., Shevkani, K., Katyal, M., Singh, N., Ahlawat, A. K., \& Singh, A. M. (2016). Physicochemical and rheological properties of starch and flour from different durum wheat varieties and their relationships with noodle quality. Journal of Food Science and Technology, 53(4), 2127-2138. https://doi.org/10.1007/s13197-016-2202-3

Kruger, J. E., Matsuo, R. B., \& Dick, J. W. (1996). Pasta and Noodle Technology. St. Paul, MN: American Association of Cereal Chemists.

Lawal, O.M., Fogliano, V., Rotte, I., Fagbemi, T.N., Dekker, M. \& Linnemann, A.R. (2021). Starch invitro-digestibility and micronutrient bioaccessibility of leafy vegetable fortified yellow cassava pasta. (manuscript under review).

Lawal, O. M., Talsma, E. F., Bakker, E., Fogliano, V., \& Linnemann, A. R. (2021). Novel application of biofortified crops: consumer acceptance of pasta from yellow cassava and leafy vegetables. Journal of the Science of Food and Agriculture, 101, 6027-6035. https://doi.org/10.1002/jsfa.11259. In press.

Leonel, M., de Souza, L. B., \& Mischan, M. M. (2011). Thermal and pasting properties of cassava starch-dehydrated orange pulp blends. Scientia Agricola, 68(3), 342-346.
Lu, H., Guo, L., Zhang, L., Xie, C., Li, W., Gu, B., \& Li, K. (2020). Study on quality characteristics of cassava flour and cassava flour short biscuits. Food Science \& Nutrition, 8(1), 521-533. https://doi.org/10.1002/fsn3.1334

Mercier, S., Moresoli, C., Mondor, M., Villeneuve, S., \& Marcos, B. (2016). A metaanalysis of enriched pasta: what are the effects of enrichment and process specifications on the quality attributes of pasta? Comprehensive Reviews in Food Science and Food Safety, 15(4), 685-704. https://doi.org/10.1111/1541-4337.12207

Michalak-Majewska, M., Teterycz, D., Muszyński, S., Radzki, W., \& Sykut-Domańska, E. (2020). Influence of onion skin powder on nutritional and quality attributes of wheat pasta. PLoS One, 15(1), Article e0227942. https://doi.org/10.1371/journal. pone.0227942

De Moura, F. F., Moursi, M., Lubowa, A., Ha, B., Boy, E., Oguntona, B., ... MaziyaDixon, B. (2015). Cassava intake and Vitamin A status among women and preschool children in Akwa-Ibom, Nigeria. PLoS One, 10(6), Article e0129436. https://doi.org/ 10.1371/journal.pone.0129436

Noordraven, L. E. C., Bernaerts, T., Mommens, L., Hendrickx, M. E., \& Van Loey, A. M. (2021). Impact of cell intactness and starch state on the thickening potential of chickpea flours in water-flour systems. LWT, 146, Article 111409. https://doi.org/ 10.1016/j.lwt.2021.111409

Ocheme, O. B., Adedeji, O. E., Chinma, C. E., Yakubu, C. M., \& Ajibo, U. H. (2018) Proximate composition, functional, and pasting properties of wheat and groundnut protein concentrate flour blends. Food Science \& Nutrition, 6(5), 1173-1178. https:// doi.org/10.1002/fsn3.670

Odey, G. N., \& Lee, W. Y. (2020). Evaluation of the quality characteristics of flour and pasta from fermented cassava roots. International Journal of Food Science \& Technology, 55(2), 813-822. https://doi.org/10.1111/ijfs.14364

Odoemelam, C. S., Percival, B., Ahmad, Z., Chang, M.-W., Scholey, D., Burton, E., Wilson, P. B. (2020). Characterization of yellow root cassava and food products: Investigation of cyanide and $\beta$-carotene concentrations. BMC Research Notes, 13(1), 333. https://doi.org/10.1186/s13104-020-05175-2

Ojo, M. O., Ariahu, C. C., \& Chinma, E. C. (2017). Proximate, Functional and Pasting Properties of Cassava Starch and Mushroom (Pleurotus pulmonarius) Flour Blends. American Journal of Food Science and Technology, 5(1), 11-18. 〈http://pubs.sciepub. com/ajfst $/ 5 / 1 / 3\rangle$.

Oladunmoye, O. O., Akinoso, R., \& Olapade, A. A. (2010). Evaluation of some physicalchemical properties of wheat, cassava, maize and cowpea flours for bread making. Journal of Food Quality, 33(6), 693-708. https://doi.org/10.1111/j.17454557.2010.00351.x

Oladunmoye, O. O., Aworh, O. C., Maziya-Dixon, B., Erukainure, O. L., \& Elemo, G. N. (2014). Chemical and functional properties of cassava starch, durum wheat semolina flour, and their 552 blends. Food Science \& Nutrition, 2(2), 132-138. https://doi.org/ $10.1002 /$ fsn 3.83

Oliviero, T., \& Fogliano, V. (2016). Food design strategies to increase vegetable intake: The case of vegetable enriched pasta. Trends in Food Science \& Technology, 51, 58-64. https://doi.org/10.1016/j.tifs.2016.03.008

Omimakinde, A. J., Oguntimehin, I., Omimakinde, E. A., \& Olaniran, O. (2018). Comparison of the proximate and some selected phytochemicals composition of fluted pumpkin (Telfairia occidentalis) leaves and pods. International Biological and Biomedical Journal, Autumn, 4(4), 206-212.

Panghal, A., Kaur, R., Janghu, S., Sharma, P., Sharma, P., \& Chhikara, N. (2019). Nutritional, phytochemicals, functional and sensorial attributes of Syzygium cumini 1 . pulp incorporated pasta. Food Chemistry, 289, 723-728. https://doi.org/10.1016/j. foodchem.2019.03.081

Rachman, A., Brennan, M. A., Morton, J., \& Brennan, C. S. (2019). Effect of cassava and banana flours blend on physicochemical and glycemic characteristics of gluten-free pasta. Journal of Food Processing and Preservation, 43(9). https://doi.org/10.1111/ jfpp. 14084

Rathod, R. P., \& Annapure, U. S. (2017). Physicochemical properties, protein and starch digestibility of lentil-based noodle prepared by using extrusion processing. LWT Food Science and Technology, 80, 121-130. https://doi.org/10.1016/j.lwt.2017.02.001

Sakurai, Y. C., Rodrigues, A. M., Pires, M. B., \& Silva, L. H. (2019). Quality of pasta made of cassava, peach palm and golden linseed flours. Food Science and Technology, 40(1), 228-234. https://doi.org/10.1590/fst.09119

Sato, R., Cilli, P. L., de Oliviera, B. E., Maciel, B. V., Venturini, A. C., \& Yoshida, C. M. (2019). Nutritional Improvement of Pasta with Pereskia aculeata Miller: A NonConventional Edible Vegetable. Food Science and Technology, Campinas, 39(1), 28-34. https://doi.org/10.1590/fst.35617

Sharma, R., Dar, B. N., Sharma, S., \& Singh, B. (2021). In vitro digestibility, cooking quality, biofunctional composition, and sensory properties of pasta incorporated with potato and pigeon pea flour. International Journal of Gastronomy and Food Science, 23. https://doi.org/10.1016/j.ijgfs.2020.100300

Simonato, B., Tolve, R., Rainero, G., Rizzi, C., Sega, D., Rocchetti, G., ... Giuberti, G. (2020). Technological, nutritional, and sensory properties of durum wheat fresh pasta fortified with Moringa oleifera 1. leaf powder. Journal of the Science of Food and Agriculture. https://doi.org/10.1002/jsfa.10807

Simonato, B., Trevisan, S., Tolve, R., Favati, F., \& Pasini, G. (2019). Pasta fortification with olive pomace: effects on the technological characteristics and nutritional properties. LWT Food Science and Technology, 114. https://doi.org/10.1016/j. lwt.2019.108368

Sobota, A., Wirkijowska, A., \& Zarzycki, P. (2020). Application of vegetable concentrates and powders in coloured pasta production. International Journal of Food Science \& Technology, 55(6), 2677-2687. https://doi.org/10.1111/ijfs.14521

Sobowale, S. S., Olatidoye, O. P, Olorode, O. O, \& Akinlotan, J. V (2011). Nutritional potentials and chemical value of some tropical leafy vegetables consumed in South West Nigeria. J. Sci. Multidiscip. Res., 3, 55-65. 
Suman, M., De Maria, R., \& Catellani, D. (2008). Chromatographic evaluation of chlorophyll derivatives in pasta-based food products: effects of pasteurization treatments and correlation with sensory profiles. Journal of the Science of Food and Agriculture, 88(3), 471-478. https://doi.org/10.1002/jsfa.3109

Tharise, N., Julianti, E., \& Nurminah, M. (2014). Evaluation of physicochemical and functional properties of composite flour from cassava, rice, potato, soybean and xanthan gum as an alternative to wheat flour. International Food Research Journal, 21 (4), 1641-1649.

Zen, C. K., Tiepo, C. B. V., da, S. R. V., Reinehr, C. O., Gutkoski, L. C., Oro, T., \& Colla, L. M. (2020). Development of functional pasta with microencapsulated spirulina: technological and sensorial effects. Journal of the Science of Food and Agriculture, 100(5), 2018-2026. https://doi.org/10.1002/jsfa.10219 